\title{
FOREIGN EXPERIENCE OF IMPLEMENTING THE SYSTEM OF AESTHETIC EDUCATION OF THE YOUNGER GENERATION
}

\author{
Tamara Pahuta \\ Candidate of Pedagogical Sciences, Associate Professor, \\ Headmaster of Pedagogical Education Institute, Academician Stepan Demianchuk \\ International University of Economics and Humanities, Ukraine \\ e-mail: tamara.paguta@ukr.net, orcid.org/0000-0003-2266-6869
}

\section{Summary}

The issues of aesthetic education and development of aesthetic culture among the younger generation are the topical issues today. Personal orientation of modern education provides young peoples involvement in the aesthetic experience of humanity, creative activities, which are the base of personal aesthetic development. Aesthetic education is one of the primary schools educational system directions. It is realized in unity with the mental, moral, physical and labor education of primary schoolchildren and acts as a necessary factor in the comprehensive development of personality.

Aesthetic education is an integral part of a harmoniously developed personality formation, a necessary condition for the spiritual development of human, his moral stability, creative attitude to work. Today we face the problems that children do not understand the aesthetic meaning of artistic values, the low level of schoolchildrens aesthetic consciousness, the lack of true spirituality. Nowadays the aesthetic education is one of the problems, which solution will influence the further development of culture.

The purpose of our research is to determine ways of implementing the system of younger generations aesthetic education in Ukraine, based on the analysis of foreign experience.

There were used these theoretical methods of research in the process of writing this article: the analysis of psychological, pedagogical and methodological literature on the problem of research; synthesis of the basic research concepts of; formulation of conclusions on the problem.

Keywords: system approach, goalmotivation, informative, operationally-functional and diagnostically-effective components.

\section{DOI: https://doi.org/10.23856/3863}

\section{Introduction}

The determination of the main goal presented in the model based on the principles of personality-oriented education is the essence of primary school childrens aesthetic education system. Its internal capabilities are revealed, which determine the achievement of the intermediate goal and objectives, at the same time. The gradual organization of the educational process which forms humanistic value orientations, artistic and aesthetic knowledge and skills involves achieving the previous stages goal, which is a mandatory and sufficient condition for the effectiveness of the next phase. The essence of aesthetic education is an important design tool, because in the modeless development and organizational decision, its choice is the first and most responsible algorithm. The strategy of aesthetic education is the base for all artistic and aesthetic education directions, at the same time, the subordination of all processes components provides the expected quality of artistic and aesthetic education. 
The system of aesthetic education is a purposeful, holistic, creative pedagogical process based on a holistically-integrated approach and the concept of dialogue interaction in the process of development and assimilation artistic and aesthetic knowledge and skills, activated by value orientations. This gives us a possibility to solve the problem of artistic and aesthetic development of the junior students' personality; to fully realize the artistic and aesthetic potential inherent in academic disciplines, to increase their artistic and aesthetic capacity; to lay the artistic and aesthetic foundations of education; to create conditions for going beyond program school education.

\section{The concept of aesthetic education}

The aesthetic education is a complex and multifaceted phenomenon that can be called a "system of aesthetic education". The system approach contributes to the construction of an educations holistic system as a set of all their components (phenomena, processes, influences, stages), the interaction of which generates a new system quality. A systematic approach to the schoolchildrens' aesthetic education involves the consistent implementation of all its tasks by all available means. The influence of the family, school, mass media, and out-of-school educational institutions should be taken into account and coordinated here.

We noticed that there are different approaches to the definition of "education system" and "aesthetic education system", while analyzing the psychological and pedagogical literature

In particular, V. Bespalko determines a pedagogical system as a set of interconnected tools, methods and processes necessary to create an organized, purposeful and intentional pedagogical influence on the formation of personality with given qualities (Bespalko, 1989: 6). To his mind, the main components of this system are: students; tasks of education (general and partial); the content of education; processes of education (self-education and training); teachers (or TTA - technical teaching aids); organizational forms of educational work.

N. Kuzmina defines the pedagogical system as a set of interconnected structural and functional components, subordinated to the tasks of younger generations' and adults' upbringing, education and training (Kuzmina, 1980: 11).

According to O. Semashko, "The system of aesthetic education includes all the diversity of aesthetic and educational activities, namely the main aesthetic influences' areas, the principles that determine the content, forms and methods of work. There is a content of the system at certain levels: a) scientific (education system acts as a holistic theory); b) educational and methodical (system is reflected in documents and textbooks); c) practical (introduction of aesthetic education with the help of various organizational forms and educational works' means)" (Semashko, 1980: 76).

A. Kartalov believes that the system of aesthetic education is "an internally organized set of components (spheres of aesthetic action, means, factors, institutions, organizations, etc.), which are in a certain relationship and interaction... The structure of the aesthetic educations' system includes the following components: the object of aesthetic education, the object of system management, aesthetic value, volitional orientation" (Kartalov, 1980: 33).

O. Dubaseniuk notes that "the system of aesthetic education is a purposeful, organized process of artistic and aesthetic education, development, childrens' upbringing, which is built on the basis of a methodological principles complex, psychologically and pedagogically resonabled methodological documents that ensure implementation in interrelation with aesthetic education of the personality, his moral and labor development" (Dubasenyuk, 2004: 361). 
B. Nemensky believes that the school should "have a single system of aesthetic education, which covers and combines not only the subjects of the art cycle and extracurricular activities, but literally permeates the whole childs' life, where each subject, each type of activity has its own clear conception for the whole life of the kid" (Nemensky, 1987: 59).

The system of aesthetic education includes the main components: the purpose and objectives of education, methodological approaches to determining the content, forms and methods of its implementation, the presence of educational institutions that carry out younger generations' aesthetic education. We believe that the structure of the primary school students' aesthetic education system includes four components: goalmotivation, semantic, operationally-functional and diagnostically-effective.

The goalmotivating component involves defining the goals, tasks, motives and principles of aesthetic education.

The semantic component provides the formation of childrens' aesthetic consciousness (aesthetic ideal, aesthetic concepts, aesthetic views, aesthetic feelings, aesthetic tastes), on the basis of which aesthetic activity is formed (playing, educational, working, behavioral, communicative).

Operationally-functional component includes tools (various arts, nature, life, media), methods (story, conversation, explanation, review of illustrations, paintings, observations, exercises) and forms of work with children (lessons, electives, tours, workshops, studios of aesthetic education, exhibitions, educational activities).

The diagnostic and effective component involves the use of various methods to determine the level of primary school childrens' aesthetic education.

An aesthetic education has a two-level structure, according to the systematic approach. The first level provides a clear definition of the purpose and tasks of the system, methodological approaches to determining the content, forms and methods of its implementation. It is necessary to take into account the development of the physiological and psychological basis of aesthetic culture; the development of the perception culture and evaluation of artistic and aesthetic phenomena from the standpoint of form and content unity; education of aesthetic taste in its unity with the aesthetic ideal; development of the emotional personality's sphere. In order to achieve the goal and realize the tasks it is necessary to take into account the age features of younger students.

The second level involves the definition of educational and cultural institutions, events and activities that are vocated to implement through organizational forms basic aesthetic tasks and achieve goals.

The external structure must be in agreement with the internal content requirements so that each child could achieve the highest possible level of aesthetic education and aesthetic development. Unity, conformity, interaction of external and internal structures are the essence of an effective aesthetic educations' system. Such a system, built on the unity of semantic tasks and the most effective forms of their solution, is the core of the aesthetic educations' system.

\section{Foreign experience in aesthetic education of children}

There is a need to turn to the analysis of aesthetic education systems abroad in order to study these issues more detailed. As follows, the content of this study is not only the analysis of specific concepts or methods of aesthetic education, but also the characteristics of the conditions that in practice constitute the unity of life, art, education, which in its aesthetic impact gives such a positive effect, forming a common lifestyle, special order worldview, 
imbued with an aesthetic perception of the world and a sense of deep involvement in it and its manifestations.

The ideas of aesthetic educations ' humanistic pedagogy are extremely relevant for the modern Ukrainian primary school. Technologization of aesthetic educational space involves special construction of didactic materials' educational content, methodical guidelines for its use, types and educational dialogue, forms of control over the students' aesthetic development in the process of educational and cognitive activities. There are many personality-oriented educational technologies used in primary school nowadays, but there are few special studies directed to educate aesthetic attitudes and to form aesthetic attitudes to the environment and so on. The existing studies address the outlined issues of this study only fragmentarily or indirectly. That's why we resorted to the foreign experience analysis of junior schoolchildrens` aesthetic education.

There are well known Waldorf pedagogy, Maria Montessori school, the concept of Celeste Frenet, developmental learning technologies, group learning activities in foreign systems and learning technologies. Let's dwell briefly on the analysis of each.

Waldorf pedagogy is characterized as a system of self-knowledge and self-development of the childs' personality in partnership with the teacher. It is based on R. Steiner's anthroposophical teaching on the individuality of a person, the main components of which are body, soul and spirit. A fundamental position of Waldorf pedagogy is R. Steiner's concept of humans' seven years rhythm development. Great importance is attached to the word of the teacher and the practical actions of students in primary school. The principle of nature compliance acts, when it comes to the formation of reading, writing and calculation skills, taking into account the readiness of the child for this activity

The theoretical basis of learning technology in the Waldorf school is directed on the holistic education of the student's personality, taking into account the peculiarities of his development. Therefore, the most important requirement is a deep study of the childs' personality, his thinking, character, will, memory, and so on. Acquaintance with children takes place before entering school (Pavlenko, 2012: 364).

The exceptional importance is attached to the pedagogical impact of the environment. Waldorf teachers strive to deepen children's sense of connection with nature: "What is good for nature is always good for people". That's why children are taught to.

Waldorf schools exist in different countries: Germany, Switzerland, England, Israel, Austria and others. Since 1995 these scools have been operating in Ukraine: two schools in Odessa, one in Donetsk, one in Dnipro and one in Kropyvnytskyi. There are centers of the Waldorf Initiative in Kharkiv, Lviv, Kyiv, and Ivano-Frankivsk.

There are high demands to the teacher of the Waldorf school. He must be a highly spiritual person, have a deep knowledge of the philosophical foundations of anthroposophy, play musical instruments, speak three languages (native and two foreign).

The technology of the Waldorf school is relevant for our research, because the purpose of this study is the aesthetic education of students while studying most of subjects. Particularly the borrowing of certain approaches to the formation of children's sense of beauty in nature and the environment is relevant for us.

The next system of primary education, which is widely used in Western schools, is the school of Maria Montessori. Interestingly, this system is also a model of personal learning. It is based on the idea that each child with its individual capabilities, needs, system of relationships goes through its own, individual path of development. The creed of an outstanding teacher is the experimental research of a child in the conditions of his free upbringing in a specially 
organized environment. In Montessori's concept, attention is paid to the issues of continuing the "lines" of preschool development in the pedagogy of primary education. M. Montessori believes that the dominant teaching methods should be practical actions with didactic material for various purposes, taking into account such a feature of the development of primary school children as mobility. Cognitive epistemological activity is a key for our system of aesthetic education as we found in the previous section of the study.

Montessori school is built on the ideas of free, environmentally friendly upbringing of the child on the basis of independence and self-education. The main principles of such education are creation of a pedagogically appropriate educational and developmental environment, strong connection with nature, constant study of the childs' personality in activities, cooperation with adults and other children, work of children in different age groups, education of aesthetic feelings, kids` self-esteem, self-knowledge their abilities, training in self-discipline, self-organization and order, close contact with parents.

Montessori's pedagogical system found its supporters not only in Italy, Belgium, Germany, Holland, USA, France, England, but also in Ukraine. Montessori`s school began its work in Kyiv in 1992. Teachers and educators clearly adhere to the three main positions of this pedagogical theory: education should be free, individual, based on observations of the child and the main principle: "Help me to do it myself” (Dubyaga, 2015: 17).

Apparently, certain positions of the Montessori system can be reflected in our system of aesthetic education.

The pedagogical concept of the French teacher Celesten Frenet is very popular in the countries of Western Europe. Its main features are mandatory consideration of the peculiarities of age psychology and the diversity of children`s abilities and inclinations, purposeful stimulation of their intellectual and emotional activity, socially useful work at all stages of learning, creating an effective system of school self-government. S. Frene realized his plans not through individual methods, but through numerous "educational technologies" and "new material ways of teaching and education". The leading role in education belonged to eight laboratories and workshops, where children were engaged in various types of work.

In recent decades, researchers have been increasingly drawn to developmental learning technologies, which are associated with the possibility of fundamental changes in schools. Developmental learning is based on the theory of L. S. Vygotsky: "Pedagogy should focus not on yesterday, but on tomorrows' child development. Teaching is good only when it is ahead of development" (Vygotsky, 1956).

One of the developmental learning theories is the theory of L.V. Zankov. To his mind, development is a manifestation in the childs' psychics of neoplasms in all areas of the psychics: the mind, will and feelings of students. The main principles of L.V. Zankovs' system are: training at a high level of difficulty; leading role of theoretical knowledge; study of program material at a fast tempo; general development of all students, both weak and strong (Zankov, 1968).

The developmental training of D.B. Elkonin - V.V. Davydov became widespread in primary schools of Ukraine. Давидова. The basis of this system is the position according to which a child is considered as a subject of learning. The main purpose of developmental learning is the formation of active, independent creative thinking of the student, and as a result a gradual transition to independent learning. While the main goal in a traditional school is to teach a student to read, write, count, in developmental learning it is to form educational activities (setting a learning task, planning a course of action, reflection) (Davydov, 1986; Dusavitsky, 1996).

The learning process of this system is based on such principles: from abstract to concrete, from general to partial. First of all children learn the general concepts which form the 
basis of the subject, then learn the specific phenomena of this concept in developmental classes. Students find a common way to solve this type of problems, by solving a concrete problem. This approach allows children to form theoretical thinking.

Analysis of the developmental learning concept gives us grounds to conclude that most of this concepts ' positions can be implemented in our system of aesthetic education, as the principle from general to specific demonstrates the process of aesthetic feelings formation most complete.

The next system of alternative learning activities was defined as group activity.

The group form of educational activity arose as an alternative to the traditional one. It is based on the ideas of J.-J. Rousseau, J.G. Pestalozzi, J. Dewey on the free development and upbringing of the child. Group work in the classroom is a form of learning organization in small study groups based on cooperation with clearly defined tasks for students united by a common learning goal. This approach contributes to the formation of cooperation and communication skills.Working in small groups is characterized by such features as The interdependence of group members, personal responsibility of each group member for their own successes and the successes of their partners, joint educationally-cognitive and creative activity of students in the group, general assessment of the group work, which consists of students ' communication form the assessment along with the academic results of work (Nor, 1996).

Group learning activities do not isolate students from each other, as the frontal and individual do, but vice versa, allows you to realize the natural desire for communication, mutual assistance and cooperation.

The analysis of the existing systems and concepts of teaching in primary school showed that primary school uses a significant amount of educational technologies today, but does not have clear tasks for the teacher. Therefore, the primary school needs to offer a general, cognitive-activity system of educating students, which would teach them to think, acquire knowledge independently with the benefit of further existence in the environment. To our opinion, the system of aesthetic education fully corresponds these requirements and can be offered for implementation in primary school. Thus the special role in structure of educational process is given to aesthetic education as the most important way of the creative personality formation and development.

The theory and practice of aesthetic education in Western countries are interesting for many reasons, primarily because the conclusions of researchers are checked by them, usually experimentally. The philosophical foundations of aesthetic education in the United States are interesting in this regard, because there are no compulsory school programs and a single type of school, and therefore the American education system in all its components is characterized by wide variability.

Philosophical concepts of aesthetic education in the United States are based on the theory that modern society is characterized by such features: the dominance of science and technology, which sometimes leads to technocracy; excessive interest in the functional; tension and anxiety; loss of individuality; total unification. American educators recognize art as a panacea for many educational problems. Therefore, the American pedagogical literature emphasizes the special role of artistic experience for the lives of all nation's future members and promotes mandatory art classes for every child, regardless of his talent. It should be noted that aesthetic education is seen there, mainly as education through art, mostly through the childs' own practice, not through the perception of works of art. It is assumed that life observations find aesthetic significance only through the prism of practical artistic experience.

According to this, US educators consider that one of the main goals of aesthetic education is the establishment of an emotional balance between personality and environment, the 
accumulation of positively colored subjective experience. We found the most consistent expression of the emotional balance idea in Victor Lowerfeld's "therapy through art" concept, based on the assumption that the main reason for the loss of children's life confidence is the inability to express their opinion in words. The whole terminological hierarchy is connected with therapy through art, which has passed into the American works on questions of aesthetic education from $Z$. Freud's theory and behaviorist psychology. These are self-expression, self-realization, self-confidence, and finally self-evaluation. These aspects of worldview in American theory are called with a general term - "personal adjustment", that is the balance of personality with the environment.

French and British researchers recognize the American education system as a model for the future of their countries. The policy of official state authorities on aesthetic education is more conservative in the countries of the old world, particularly in France, in contrast to the United States. There are unified state programs (France) or a system of state final exams (England), forcing teachers to familiarize themselves with the rules inherited from traditional art teaching systems frontally. Western educators aim to overcome intuitionism in practical teaching and in the theoretical analysis of the artistic process. The positions of theorists and practitioners of aesthetic education in relation to the same problems are so contradictory at the same time that it is difficult to point the "average" concept of the Americans, French or British (Sedova, 2001).

Communication between aesthetic education specialists in the United States, England and France is carried out through professional journals, as well as through national and international pedagogical societies. For example, the National Association for Aesthetic Education was established in the USA, and the Royal Society for Education through Art was established in England. Similar societies exist in France, Italy, Germany and other countries. A large number of books and special annual publications and magazines on the problems of aesthetic education are published in the United States, England and France. The most typical directions of foreign pedagogy and aesthetics basically coincide with the directions and schools of modern philosophy. The influence of such philosophical schools as Freudianism, pragmatism, neotomism and existentialism has been denoted in scientific researches. The practical application of this researches by figures of foreign pedagogy is as interesting as the theoretical search.

The analysis of scientific publications and special studies has shown that modern Western educational institutions attach special importance to active methods of aesthetic education. Proponents of this approach believe that the main thing in education is the overall childrens ' development, which ultimately determines the success of learning, not only the input of knowledge to children.

Western schools of labor allow great importance to the system of aesthetic education, children's activities in general, in contrast to purely verbal methods of teaching and education. Moreover, the initiative of both students and educators is encouraged. The modern school considers the obligatory program, an estimation of progress of pupils, examinations outdated and optional. Instead, diaries are practiced as a means of systematically recording the development of the child's personality; questionnaires which find out childrens' interests and knowledge. Learning and development, rational origin and intuition, search for an objective system that ensures the acquisition of all students the necessary knowledge and skills in the field of basic sciences, on the one hand, and the disclosure of individual creative potential of children as the main goal of educational work at school, on the other hand, that is the approximate list of questions around which there is a struggle between new and old systems of education and training.

The aesthetic upbringing of children in France is, as it were, in transitional stage, where the ideas of the new American school are becoming clearer. However, it should be noted that 
the term "aesthetic education" is largely narrowed and limited to the field of art education, in contrast to the "Ukrainian" concept. The typical desire of the entire French nation to artistic taste should be noted while speaking of the philosophical foundations of aesthetic education in France.

Aesthetic education in French schools plays a significant role in the overall national development. Also the national importance is given to it. Therefore, aesthetic education at school applies to all students without exception, not only the particular group of gifted children.

French schools have textbooks in art disciplines, including drawing and singing, along with textbooks in general education subjects. The school produces special series of paintings reproductions and musical compositions, with a rich repertoire, using school radio and television. Modern art is widely represented, along with examples of classical art.

Modern French art and its methodological concepts have a significant impact on the content and direction of childrens' aesthetic education. Researchers of modern approaches to aesthetic education point out that the scientific basis of aesthetic education should be based on modern psychology, philosophy and aesthetics, and note the principles of Bergson, Nietzsche, Freud The founders of the art education system rightly believe that the systematic encouragement of childrens ' creative pursuits have particular importance for their artistic activities. Children find their individual aesthetic expression in this search. It is emphasized that this experience cannot be replaced, as the "traditional school" is trying to do. That's why children perform and create music, not only listening to it.

\section{Conclusions}

Thus, the analysis of the aesthetic education content in Western schools makes it possible to note in these systems a number of interesting and progressive points. In this regard, we should mention the theory of "creativity" by John Guilford, the theory of quality problem solving by means of art by Charles Pierce and John Dewey (USA), the theory of education through art by Herbert Reed, the theory of social role of art by Alfred Norton Whitehead (England), the theory of religious education by means of art Jacques Maritain (France).

Bringing the child's activities to the forefront, his creativity, high appreciation of this activity and childrens ' creative work in comprehensive humanistic education, the search for active educational methods as opposed to teaching, affirming the importance of expressiveness in children's art education are advanced comparing to the traditional system of education and causes interest in the further development of such a system and its educational results.

However, it should be noted that aesthetic education in Western schools is aimed at identifying the role of art in general education, overcoming narrow specialization, eliminating the overload of teaching art with didactic and narrow technical tasks, refraining from underestimating the imagination as one of the main factors of creative personality development.

\section{References}

Bespal'ko, V. P. (1989). Slagayemyye pedagogicheskoy tekhnologii [The terms of pedagogical technology]. Moscow. Pedagogika. [in Russian].

Vygotskiy, L. S. (1956). Izbrannyye psikhologicheskiye issledovaniya [Selected psychological research]. Moscow. [in Russian].

Dubasenyuk, O. A. (2004). Praktykum z pedahohiky: navchal'nyy posibnyk. [Workshop on pedagogy: a textbook]. Kyiv. Tsentr navchal'noyi literatury. [in Ukrainian]. 
Zankov, L.V. (1968). Didaktika i zhizn' [Didactics and life]. Moscow. Prosveshcheniye. [in Russian].

Kartalov, A. (1980). Sistema esteticheskogo vospitaniya studentov [System of aesthetic education of students]. Esteticheskoye vospitaniye studentov: sb. nauch. st. Moscow. Politizdat. [in Russian].

Kuz'mina, N. V. (1980). Metody sistemnogo pedagogicheskogo issledovaniya: ucheb. Posobiye [Methods of systemic pedagogical research: textbook. allowance]. leningrad. LGU. [in Russian].

Nemenskiy, B. (1987). O problemakh esteticheskogo vospitaniya : kniga dlya uchitelya / 2-ye izd., pererab. i dop. [On the problems of aesthetic education: a book for a teacher]. Moscow. Prosveshcheniye. [in Russian].

Nor, E. F. (1996). Tekhnologiya organizatsii gruppovoy uchebnoy deyatel'nosti. [Technology of organization of group educational activity]. Nikolaev. [in Russian].

Pavlenko, V.V. (2012). Ideyi R. Shtaynera u suchasniy osvitniy systemi Ukrayiny [Steiner's ideas in the modern educational system of Ukraine]. Innovatsiynyy dosvid pedahohiv doshkil'noyi ta pochatkovoyi osvity Zhytomyrshchyny: zbirnyk naukovo-metodychnykh prats' / za zah. red. V.YE. Lytn'ova, N.YE. Kolesnyk. Zhytomyr. FOP Levkovets'. [in Ukrainian].

Dubyaha, S. M. (2015). Pedahohichni tekhnolohiyi v pochatkoviy shkoli: Navchal'no-metodychnyy posibnyk dlya studentiv vyshchykh navchal'nykh zakladiv napryamu pidhotovky "Pochatkova osvita" [Pedagogical technologies in primary school: Educational and methodical manual for students of higher educational institutions in the direction of preparation "Primary education"']. Melitopol': Vydavnytstvo MDPU imeni B. Khmel'nyts'koho. [in Ukrainian]. Sedova, L. N. (2001). Dialog kul'tur v sovremennom obrazovanii [Dialogue of cultures in modern education]. Dialogue of cultures: XXI century. Balashov: Izd-vo BGPI. [in Russian].

Semashko, A. N. (1980). Sistema i printsipy esteticheskogo vospitaniya studenchestva [The system and principles of aesthetic education of students]. Esteticheskoye vospitaniye studentov. Moscow. Prosveshcheniye. [in Russian]. 